\section{Problems of development aid}

SIR-The world is experiencing more frequent collapses of natural resource systems leading to disasters that require international relief. But many of these disasters are themselves the ecological consequences of previous 'development' aid $^{1}$. The reasons are illustrated by a recent paper from the International Institute for Environment and Development $^{2}$ on evaluating success in resource management projects in developing countries. We are not criticizing the paper, but use it to point to a widespread limitation in thinking about development aid, namely lack of attention to space and time scales in assessing the dynamics of ecological systems.

The problem is this: the success of aid projects has been judged (1) by criteria more relevant to the donor country than to the recipient, such as completion of wells and dams; and (2) subjectively by outsiders, on single visits, with conclusions reached by consensus. Skinner ${ }^{2}$ has suggested alternative criteria that include whether (a) resource use is sustainable, (b) local people benefit in their own estimation and (c) projects meet local government goals. But, these criteria also cause, in the long term, rapid population increase, negation of project benefits, degradation of ecosystems and increase of poverty ${ }^{1}$.

In the Sahel famine disasters, much of the blame ascribed to drought is misdirected. The 'droughts' were man-made and the ecological basis for the breakdown of the ecosystem has been described ${ }^{2.3}$. In general, the number of organisms that any ecological system can support over time depends partly upon their spatial dynamics. Systems with spatial migrations can support more consumers than equivalent systems where organisms are locally constrained, such as human agro/pastoral systems. Spatial and temporal variation are essential requirements for the persistence of most natural ecosystems ${ }^{4.5}$ yet it is an almost universal aim of policy planners and managers to prevent fluctuations and to spread things out evenly in space.

In Africa, most of the attention paid to aid has been directed towards regions surrounding the Sahara. Without the resulting permanent water supplies and settlement schemes, we contend that much of the disaster would not have occurred. But that is history. Aid organizations are now preparing to repeat the process around Africa's southern Namib-Kalahari desert. As scientists with experience of these ecological systems, we are apprehensive about what will happen to Namibia, Angola and adjacent regions in Botswana when political change allows the next round of arid region 'development'.

We urge restraint in development of permanent water supplies, use of fertilizers and so on until a thorough analysis is made of the likely ecological consequences over time and space. An essential question, which should be asked before the project is approved, is: 'Will the proposed development change the temporal/spatial dynamics of the systems? More specifically, will it lead to changes in the distributions of livestock, water (from rainfall) and soil?' If the answer is 'yes', it should be reconsidered, bearing in mind the lessons we have already learned ${ }^{1,3-5}$.

B.H. WALKER

Division of Wildlife and Ecology, CSIRO

Box 84, Lyneham, ACT 2602, Australia

Department of Zoology, A. R. E. SINCLAIR

University of British Columbia,

Vancouver V6T 2A9, Canada

1. Sinclair, A.R.E. \& Wells, M.J. in Food and Natural Resources (eds Pimentel, D. \& Hall, C.) $439-484$ (Academic, New York, 1989).

(Academic, New York, 1989). Switzerland, 1989).

3. Sinclair, A.R.E. \& Fryxell, J.M. Can. J. Zool. 63, 987 - 984 (1985)

Walker, B.H. in Conservation for the 21st Century (Western, D. \& Pearl, M. eds) (Oxford University Press, Oxford).

Walker, B.H., Emslie, R.H., Owen-Smith, R.N. \& Scholes R.J. J. appl. Ecol. 24, 381 - 401 (1987)

\section{University funding}

SIR-D. T. Elmore has questioned the validity of the negative association between Universities Funding Council (UFC) research grades and the Financial Times graduate employment statistics in UK universities (Nature 342, 729; 1989), but his report of my statistical analysis (Nature $341,562 ; 1989)$ is misleading. The negative correlation is present regardless of whether extreme outlying points are excluded from the analysis and the collation of data for colleges of the Universities of London and Wales is reported clearly, being based on the numbers of departments in each college.

The additional points made by Elmore relate to variability in graduate employment prospects and to the inadequacies of the UFC research grading process. But these speculations are not relevant to the interaction between graduate employment and UFC research grades. While I agree with Elmore that both data sets are imperfect, it is difficult to see how their inadequacies would produce any significant relationship between graduate employment records and research status, let alone a negative one.

I am forced to conclude that "in general, poor research gradings are associated with enhanced graduate prospects of gaining a foothold in the world of work". This may not be what the academic community wishes to hear, but, on the basis of the best data available, I contend that the effect is real.

Elmore suggested that my analysis is "an open invitation to government . . . to downgrade some departments or even universities unjustifiably to a teaching role only". I am not in the business of extending invitations to government, but the consequences of ten or more years of financial restraint in our universities are clear: most have arrived at a strategy for the pursuit of research and teaching where resources are limited. It is a question of emphasis and priority; which will be sacrificed first, research or teaching? That the question is asked should be a matter of concern to everyone interested in higher education in the United Kingdom.

Piecemeal cessation of research activity will only increase disparities among institutions and lead to further decline in UK science. The government should encourage universities with low research grades to do better through increased funding for tertiary level education and public sector research. This is the only realistic means whereby the United Kingdom can expand its graduate output, avoid increasing shortages of scientists and create an economic and cultural environment worthy of a developed country in the twenty-first century. For the time being, many of the poor relations among the UK university research community can take pride in the high demand for their graduates.

W. I. MONTGOMERY

School of Biology and Biochemistry,

The Queen's University of Belfast,

Belfast BT9 5AG, Northern Ireland

\section{More on Shockley}

SIR-Frederick Seitz's "Defence of Shockley" (Nature 342, 474; 1989) omits events equally as important as the traumatic automobile accident on 23 July 1961 "in evaluating his activity in later years" "his ... ill-conceived concentration on socio-genetic matters": His marriage, which had produced three children, was dissolved. John Bardeen told me (December 1966) that Shockley "tried to solve all the problems in physics, had a nervous breakdown in 1951" and entered a hospital for psychiatric care ${ }^{1}$. As reported in a 1962 biography of Shockley (based on interviews with him) ". . . there was a year or two when Shockley's greatest scientific interest was psychiatry". When he subsequently remarried, it was to a woman who "has taught psychiatric nursing both in hospitals and at Ohio State University"2.

\section{University of Illinois at}

Urbana-Champaign,

603 E. Daniel Street,

Champaign, IIlinois 61820, USA

1. Hirsch, J. SAGE Race Relations Abstracts 6, 1-65 (1981).

2. Thomas, S. Men of Space: Profiles of the Leaders in Space Research, Development, and Exploration 4, 195 (Chilton, Philadelphia and New York, 1962). 